Электронный научный журнал (Online). ISSN 2303-9922. http://www.vestospu.ru

УДК 94(470)“1914/1918”

DOI: $10.32516 / 2303-9922.2019 .31 .16$

\title{
А. А. Фортун
}

\section{Саратовское земство в годы Первой мировой войны (1914-1917 гг.): поставки хлеба на фронт}

С началом Первой мировой войны главные направления работы органов земского самоуправления сводились к организации лечения больных и раненых воинов, оказанию помощи беженцам и т.д. Однако по мере ухудшения ситуации на фронтах и в тылу власть привлекает земства для решения более масштабных общегосударственных задач, в частности обеспечения действующей армии хлебом и фуражом. На примере Саратовской губернии автор отмечает, что государство, делегировав земствам широкие полномочия в деле заготовок хлеба для армии, в то же время пыталось локализовать их деятельность определенным законодательным контролем. В итоге вынужденные следовать общеимперской продовольственной политике земства не смогли эффективно решить возложенные на них задачи.

Ключевые слова: Первая мировая война, Саратовская губерния, земство, продовольственные поставки, уполномоченный по поставкам хлеба.

Первая мировая война вынудила мобилизовать все национальные ресурсы Российской империи для успешного ведения военных действий. Решить эту проблему было возможно лишь при условии взаимодействия власти и общества. Начало войны ознаменовалось сплочением различных групп населения вокруг монархии. На этой общероссийской патриотической волне и возникли первые общественные организации, деятельность которых была нацелена на оказание помощи действующей армии. Большую роль в снабжении армии, помощи раненым и беженцам сыграли в годы войны две общероссийские организации, созданные в 1914 г.: Всероссийский городской (далее ВГС) и Всероссийский земский (далее ВЗС) союзы. В 1915 г. был учрежден Земгор ${ }^{1}$, в компетенцию которого входило обеспечение армии всем необходимым.

Анализ исторической литературы по теме показал, что опыт деятельности союзов в отечественной и зарубежной историографии исследован в основном в общеимперском масштабе (напр.: [11; 16; 18]), но практически отсутствуют исследования, затрагивающие деятельность местных организаций союза земств, роль которых выполняли губернские и уездные земские управы. С этой точки зрения не является исключением и деятельность поволжских земств, а именно Саратовского, которое еще не становилось предметом специального исследования, что и определяет актуальность выбранной темы.

Источниковая база исследования включает опубликованные и архивные материалы, многие из которых впервые вводятся в научный оборот. К их числу прежде всего относятся делопроизводственные документы, которые отложились в основном в фондах Государственного архива Саратовской области (ГАСО) (фонд 2 - Саратовское губернское правление и фонд 418 - Уполномоченный председателя Особого совещания по продовольственному делу в Саратовской губернии). Эти материалы помогли раскрыть механизмы взаимодействия губернского и уездных земств с центральными и местными органами власти по основным направлениям их деятельности.

Из опубликованных источников нами использованы земские периодические издания [22; 24; 26; 27], содержащие заметки относительно работы продовольственных органов в губернии.

\footnotetext{
${ }^{1}$ Главный по снабжению армии комитет Всероссийских земского и городского союзов (прим. ред.).
}

(C) Фортун А. A., 2019 
Электронный научный журнал (Online). ISSN 2303-9922. http://www.vestospu.ru

Использованная в работе совокупность исторических источников позволила воссоздать объективную картину деятельности земств Саратовской губернии в решении вопроса поставок хлеба для армии.

Хронологические рамки исследования ограничиваются периодом 1914-1917 гг. Выбор верхней границы обусловлен Февральской революцией 1917 г. в Российской империи.

Цель исследования - реконструкция процесса взаимодействия власти и органов земского самоуправления. Задачи исследования - выявить степень участия Саратовского земства в заготовках хлеба для армии, проследить изменения в отношениях царской администрации и земств с 1914 по 1917 г.

По справедливому замечанию А. Л. Сидорова, до войны не существовало централизованной системы закупки воинскими частями хлеба и фуража. Война поставила перед имперской администрацией задачу не только боевого, но и продовольственного снабжения армии [30, с. 479-480]. 30 июля 1914 г. Совет министров призвал незамедлительно приступить к закупкам хлеба для действующей армии у непосредственного производителя [30, с. 479]. Главноуправляющий землеустройством и земледелием (далее - ГУЗиЗ) А. В. Кривошеин указывал на желательность привлечения земств к работе по решению продовольственного вопроса. Как отмечает М. В. Оськин, продовольственное дело было передано в распоряжение ГУЗиЗ по причине того, что в годы проведения столыпинской аграрной реформы уже существовал опыт взаимодействия государственных структур и земских органов самоуправления, и в начальный период войны власть попыталась использовать сформировавшийся союз в военных целях [18, с. 193]. На местах в течение первой половины 1914 г. была создана разветвленная структура ГУЗиЗ, включавшая губернских уполномоченных, которыми в большинстве случаев, как показал в своем труде Н. Д. Кондратьев, становились председатели губернских земских управ [14, с. 169-170].

Организацией хлебозаготовок в Саратовской губернии для обеспечения армии занимался особый Комитет, руководителем которого стал председатель Саратовской губернской земской управы К. Н. Гримм. В целях успешной работы уполномоченного Саратовскую губернию поделили на районы, во главе которых стояли заведующие из числа представителей городской думы, городской управы и председателей уездных земских управ [8, л. 2-4].

Несмотря на плохой урожай 1914 г., первая кампания по закупке хлеба для армии прошла удовлетворительно. Так, в Саратовской губернии с 8 по 23 сентября 1914 г. уполномоченным К. Н. Гриммом только одной ржаной муки было закуплено 647350 пуд. [7, л. 123]. Однако в самой организации закупок выявились существенные недостатки. Один из корреспондентов «Сельскохозяйственного листка Балашовского уездного земства» с особым негодованием подчеркивал: «Хотя закупка и была поручена председателю губернской земской управы (курсив мой. - $A$. Ф.), но вся эта работа шла без участия земства» [28, с. 7]. Действительно, закупки производились непосредственно агентами уполномоченного и не у производителей, а у скупщиков. Отсюда возникает вопрос: почему план А. В. Кривошеина по снабжению армии через земства, т.е. напрямую от производителя, не удался?

В условиях рыночной экономики начала XX века в хлебопроизводящих регионах, в частности в Поволжье, наблюдалось обилие мелких торговых посредников. Их появление, по справедливому утверждению Т. М. Китаниной, обуславливалось процессом децентрализации торговли, подорвавшей монополию крупных купеческих фирм, и живучестью мелкотоварного производства в российской экономике, которая являлась питательной средой для жизнеспособности института скупщика $[13$, с. 82]. Скупщик в 
Электронный научный журнал (Online). ISSN 2303-9922. http://www.vestospu.ru

своем большинстве был выходцем из среды зажиточной части крестьянства, экономическое усиление которой явилось следствием социального расслоения деревни. Исследователь рынка Поволжья Н. Ф. Тагирова отмечала, что основные ключевые позиции по совершению всех торговых операций на рынке принадлежали местным скупщикам [31, c. 74 -76]. Зачастую скупщики перекупали зерно у крестьян по ценам ниже рыночных, перехватывая их обозы на пути к рынкам [32, с. 77].

В противовес скупщикам местное земство старалось организовать сбыт зерна крестьянами. Однако из этого ничего не получалось. Саратовские земские периодические издания свидетельствовали, что крестьяне фактически находились во власти скупщиков. В с. Турки осенью 1914 г. почти вся ссыпка была сосредоточена в руках торгового дома Алифанова и скупщика Фрида [28, с. 8]. Неудивительно, что земства при подобной конъюнктуре на рынке хлебов, действуя в рамках отведенных им компетенций ГУЗиЗ (осуществлять закупки по предельным ценам), не могли выдержать жесткой конкуренции в борьбе за производителя. Однако государство не поднимало закупочные цены. В результате большая часть урожая к моменту закупок (сентябрь 1914 г.) была сконцентрирована в руках скупщиков-спекулянтов, ставших своего рода монополистами, и уполномоченному по закупке хлеба пришлось закупить у них около $60 \%$ всех хлебных запасов губернии [28, с. 4]. Но, несмотря на то что уездные земства не были привлечены к работе по заготовке хлеба для армии, они не могли оставаться в стороне. Так, Балашовское уездное земство обращалось с многочисленными ходатайствами в отделение Государственного банка о введении хлебозалоговых операций. В конечном итоге это дало некоторые положительные результаты. Крестьяне, задержавшие хлеб путем залога, продали его в феврале и марте 1915 г. с надбавкой 30-50 копеек за пуд [27, с. 5].

Неудовлетворительная организация хлебной кампании 1914 г. заставила уполномоченного пойти на сотрудничество с кооперативными учреждениями, занимавшимися хлебной торговлей. В июне 1915 г. в Саратове под председательством К. Н. Гримма состоялось совместное совещание председателей уездных управ и представителей кредитных кооперативов. Здесь обсуждался вопрос об участии уездных земств в деле снабжения армии. В итоге выяснилось, что из 10 председателей уездных управ только три (Вольская, Балашовская и Кузнецкая) изъявили желание оказать содействие в деле закупки продовольствия для армии, остальные предпочли отказаться [28, с. 6]. На совещании приняли решение о том, что председатели земских управ, приступая к закупке хлеба, выступают не как представители земства, а как частные лица. Земские периодические издания видели в решении Гримма попытку председателя, с одной стороны, заручиться поддержкой органов земского самоуправления в предстоящей хлебной кампании, с другой — «...за новизной дела не перекладывать ответственность за операцию на земство (в случае провала. - А. Ф.)» [28, с. 6-7].

На фоне происходящих событий высказанная в земской печати точка зрения выглядит сомнительной. На К. Н. Гримма была возложена ответственная миссия — поставка продовольствия для действующей армии. Поэтому, соглашаясь с М. В. Оськиным, надо полагать, что в условиях неконтролируемого рынка земства не смогли получить необходимое количество товарного хлеба, не разрушая исторически устоявшихся рыночных отношений в губернии [18, с. 195]. Уполномоченный вынужден был сотрудничать с посредниками, занимавшимися торговлей хлебом в довоенный период. Следовательно, применительно к Саратовскому земству не вполне подтверждается вывод К. Мацузато о том, что закупка хлеба для армии целиком и полностью находилась в руках земств уже в $1914-1915$ гг. [16]. 
Электронный научный журнал (Online). ISSN 2303-9922. http://www.vestospu.ru

На совещании были оговорены кондиционные условия и местные предельные цены на закупаемый хлеб. Для Саратовской губернии особой комиссией под руководством К. Н. Гримма устанавливались условия для поставки ржи: цена за пуд -80 копеек при $1 \%$ сорности и при 17\% влажности. Закупки по уездам осуществлялись следующим образом: уполномоченные по уездам организовывали закупку хлеба через кооперативы, уполномоченный же по губернии производил закупку крупных партий хлеба на железнодорожных станциях или пристанях [28, с. 7].

Но как показали дальнейшие события, введенные меры лишь усугубили положение на рынке хлебов, так как твердые цены были введены лишь для закупок хлеба для армии, а цены для частной хлебной торговли не контролировались вообще. Таким образом, двойственность цен усиливала спекуляцию [20, с. 50]. В борьбе за производителя скупщики начали взвинчивать закупочные цены, что подтверждает речь заместителя уполномоченного по губернии Н. М. Булатова на чрезвычайном губернском земском собрании в августе 1915 г. Обращаясь к присутствующим, Булатов охарактеризовал весьма удручающее положение в деле закупок хлеба для армии: «...мы (земство. - А. Ф.) даем за рожь 80 коп., а скупщики сейчас же поднимают цену до 85 коп.; мы даем 85 коп., а они поднимают до 90 коп. и более. Нельзя оставаться в таком неустойчивом положении, необходимо выяснить, по какой цене мы можем покупать, чтобы цена была безубыточна, если придется покупать хлеб не только добровольно» [5, л. 72].

По итогам совещания твердые цены на рожь повысили с 80 копеек до 1 рубля 10 копеек [7, л. 72-73]. Но теперь государственные закупочные цены стали стремительно отставать от рыночных, о чем свидетельствуют цифры, приведенные в отчетах Саратовского уполномоченного (табл. 1).

Таблица 1

Повышение цен на зерно в Саратовской губернии в течение 1914-1917 гг. в процентном соотношении

\begin{tabular}{|l|c|c|c|}
\hline \multicolumn{1}{|c|}{ Основные хлеба } & $1914-1915$ & $1915-1916$ & $1916-1917$ \\
\hline Рожь & 18,2 & 42,8 & 94,9 \\
\hline Овес & 42,3 & 66,6 & 97,4 \\
\hline Пшеница & 7,0 & 56,1 & 101,0 \\
\hline
\end{tabular}

Источник: [5, л. 65-68].

Итак, огромные масштабы развернувшейся войны заставили правительство перейти к централизованным закупкам продовольствия для армии. По подсчетам П. И. Лященко, количество товарного зерна в Российской империи в 1914-1915 гг. равнялось 732 млн. пуд. Из них на нужды действующей армии государственным заготовительным аппаратом при содействии земской организации было закуплено 305 млн. пуд. [15, с. 641]. Саратовская продовольственная организация, возглавляемая К. Н. Гриммом, за указанный период смогла поставить на фронт следующее количество хлебов: пшеницы — 2900474 пуд., ржи - 4830653 и овса - 793386 пуд. [6, л. 14-14 об.]. Общая доля хлеба, поставленная Саратовской губернией, составила всего около 2,8\%. В других губерниях процентные соотношения варьировали от 0 до 10\% [21, с. 71]. Объяснялось это прежде всего тем, что твердые цены, вводимые на основные продовольственные хлеба, не позволяли быстро отвечать на изменения рыночной конъюнктуры. Поэтому хозяевами ситуации по-прежнему оставались скупщики, чье незыблемое положение обуславливалось спецификой зернового рынка.

Тем временем численный состав армии постепенно увеличивался, заготовительные операции правительства с каждым годом расширялись. Так, если в 1914-1915 гг. армия поглотила 305 млн. пуд., то в 1915-1916 гг. требовалось уже 502 млн. пуд. [30, с. 480]. 
Электронный научный журнал (Online). ISSN 2303-9922. http://www.vestospu.ru

В связи с ростом цен, увеличением объемов заготавливаемых продуктов, масштабными железнодорожными перевозками становилось ясно, что прежний аппарат по снабжению армии, как справедливо отметил А. П. Погребинский, «топтался на месте в поисках наиболее гибких организационных форм» [20, с. 51]. В этой ситуации власть была вынуждена идти на диалог с общественными организациями, в частности с Всероссийским земским и городским союзами, существенно расширяя их компетенции. Как указывает Л. А. Жукова, деятельность земств за годы войны эволюционировала от военно-санитарного дела до решения продовольственного вопроса [10, с. 305]. Однако расширяя полномочия деятельности ВЗС, ВГС, учреждений Земгора и военно-промышленных комитетов, правительство, по мнению Н. П. Ерошкина, пыталось контролировать общественные организации, опасаясь, что «общее руководство военной экономикой окажется вне его влияния, а царизм в этих вопросах может попасть в зависимость от буржуазии и буржуазных организаций» [9, с. 301-302]. И в противовес им законом от 17 августа 1915 г. правительство учредило Особое совещание по продовольствию под председательством министра земледелия А. В. Кривошеина, подотчетное только императору. При сменившем Кривошеина в ноябре 1915 г. А. Н. Наумове существенных изменений в составе регулирующего продовольственного органа не произошло [12, с. 137-138].

Совещание по продовольственному делу структурно являлось сложной организацией. В соответствии с Положением от 17 августа 1915 г. председатель Особого совещания назначал на ключевые посты своих уполномоченных. Во избежание ненужного соперничества и дублирования функций в Саратовской губернии на эту должность был назначен председатель губернской земской управы и одновременно уполномоченный Министерства земледелия К. Н. Гримм, который сосредоточил тем самым все нити продовольственного дела в своих руках. Располагая исключительными правами, уполномоченный Особого совещания осуществлял общее руководство системой заготовок и распределения продовольствия для армии и населения в губернии.

Под председательством уполномоченного на местах создавались губернские и уездные совещания, состав которых определялся по усмотрению самого уполномоченного [14, с. 172]. В их состав входили представители кооперативных союзов, военно-промышленных комитетов, торгово-промышленных организаций. Но, как показал анализ местных архивных фондов, основная доля от общего состава принадлежала председателям уездных земских управ [8, л. 3-4] как филиалов В3С. К основным задачам уполномоченного и совещания относилось: определение способа государственных продовольственных и фуражных заготовок, их стоимости, определение закупочных цен, реквизиции продуктов, скота, семян, фуража и т.д. По справедливому замечанию С. В. Бакуловой, привлекая уполномоченных от ВЗС в рабочие органы особых совещаний, власть стремилась интегрировать земство в разветвленную структуру продовольственного аппарата [3, с. 4647]. Однако сами земцы неоднократно подчеркивали, что в реальной деятельности ВЗС выходил за рамки своих компетенций [10, с. 310].

В конце сентября 1915 г. министр земледелия А. Н. Наумов подписал постановление о введении твердых цен на просо, пшено, рожь и ржаную муку, необходимых для закупки органами продовольственного снабжения армии. В современной отечественной историографии справедливо указывается на то, что твердые цены устанавливались государством поэтапно [18, с. 197]. Как считал А. Л. Сидоров, «это была фиксация корректированных вольных цен, которые просуществовали вплоть до урожая 1916 г., когда вопрос о твердых ценах вновь встанет во весь рост» [30, с. 482].

Изначально установленные твердые цены на хлеб были выше рыночных. В Саратовской губернии в 1915 г. рыночная цена на рожь составляла 92 копейки за пуд, упол- 
Электронный научный журнал (Online). ISSN 2303-9922. http://www.vestospu.ru

номоченным К. Н. Гриммом была установлена цена в 94 копейки, на пшеницу 115 и 116 копеек [5, л. 67-68 об.]. В целях ликвидации спекуляции вводилось право реквизиции хлеба по заниженным на $15 \%$ ценам [30, с. 481]. Но следует отметить, что в общеимперском масштабе угроза реквизиций применялась властями как устрашающий фактор [1, с. 176].

Начало нового 1916 г. не предвещало каких-либо серьезных катаклизмов на рынке хлебов. Местная земская печать отмечала: «...в конце июля на рынке было тихо, цены были довольно низкие и колебались мало; подвозы (хлеба. - A. Ф.) с начала августа в Саратов колебались от 500 до 1250 пуд.». Вероятно, на первых порах введение твердых цен привело к оживлению торговых операций. Более того, как замечает В. М. Рынков, введение твердых цен способствовало сокращению цепочки посредников. Государство стремилось упростить хозяйственные связи, поэтому у производителя не оставалось выбора вариантов сбыта хлеба [21, с. 75-76]. Однако уже с конца августа положение с заготовками и погрузками хлеба значительно ухудшилось. Уравновешенность рынка сменяется бешеной спекуляцией. Сложившуюся на рынке ситуацию отображает таблица 2.

Таблица 2

Повышение цен на зерно в июле — августе 1916 г., зафиксированное Саратовской биржей, коп. за пуд

\begin{tabular}{|l|c|c|c|c|}
\hline Основные хлеба & 29 июля & 9 августа & 12 августа & 26 августа \\
\hline Рожь & 125 & 135 & 140 & 190 \\
\hline Пшеница & 205 & 220 & 220 & 310 \\
\hline
\end{tabular}

Источник: [33, с. 8-11].

Как видно из приведенных в таблице 2 сведений, с 12 по 26 августа прошло около двух недель, но за этот период рожь взлетела в цене на $33 \%$, а пшеница - на $30-35 \%$. В чем же причина столь стремительного роста цен? Существенным обстоятельством, послужившим сигналом к взвинчиванию цен на зерно, стало повышение твердых цен Продовольственным совещанием при уполномоченном К. Н. Гримме, проходившим в Саратове 10-11 августа. Цена на рожь была установлена в 192 коп. за пуд, на пшеницу - в 282 коп. за пуд [33, с. 8]. Очевидно, вся атмосфера описываемого момента внушала большие надежды на то, что предложенные цены в Саратове будут утверждены в Петрограде. Один из членов ВСГ А. А. Рыбников в своем докладе отмечал, что «на местах в некоторых биржевых комитетах и земских собраниях настойчиво высказываются требования о повышении твердых цен до уровня продуктов индустрии» [33, с. 8-9]. По словам председателя Губернской продовольственной управы Н. Ф. Кожевникова, в 1916 г. «между городом и деревней начали создаваться обостренные отношения; деревня перестала получать из города продукты обрабатывающей промышленности - мануфактуру и железо, поэтому деревня почти прекратила ввоз хлеба в город» [22, с. 7-8]. Устанавливая твердые цены на продовольствие, правительство не сделало того же относительно товаров индустрии, тем самым спровоцировав резкий скачок цен на них, что не могло не отразиться на крестьянской массе.

Однако 9 сентября 1916 г. министром земледелия А. А. Бобринским твердые цены были утверждены в значительно меньшем размере, чем того требовали в Саратове. Так, вплоть до 20 ноября 1916 г. твердая цена на рожь составляла 150, пшеницу — 201, овес 154 копейки за пуд [5, л. 68]. По сути, новый министр земледелия Бобринский продолжил тактику своего предшественника А. Н. Наумова, которая заключалась в неуклонном проведении в жизнь политики твердых цен [18, с. 199], но уже не соответствующих рыночным. Причина крылась в том, что за годы войны имперские финансы значительно истощились и следовало экономить. 
Электронный научный журнал (Online). ISSN 2303-9922. http://www.vestospu.ru

Введенные меры незамедлительно сказались на общем ходе заготовок хлебов и привели к тому, что уже в сентябре 1916 г. производитель почти полностью прекратил подвоз хлеба в Саратов [33, с. 9]. Это обстоятельство серьезнейшим образом затруднило снабжение зерном центральных мельниц губернии. Недостаток пшеничного зерна (особенно мягких сортов) оказался настолько острым, что к началу ноября 1916 г. большинство мельниц г. Саратова (6 из 9) остановили свою работу, а в Царицыне мельницы не работали вообще [33, с. 10]. В результате во многих городах губернии, включая Саратов, обострился продовольственный вопрос. Как показала в своей работе Е. Ю. Семенова, уже с декабря 1916 г. в г. Вольске и в ряде других городов по карточкам выдавался не только сахар, но и мука [29, с. 171-172].

Вместе с тем в сравнении с предыдущими годами урожай 1916 г. можно охарактеризовать как неудовлетворительный, что подтверждают нижеприведенные сведения (табл. 3).

Таблица 3

Урожай хлебов в Саратовской губернии за 1913-1916 гг., пуд. с 1 дес.

\begin{tabular}{|l|c|c|c|c|}
\hline Основные хлеба & 1913 г. & 1914 г. & 1915 г. & 1916 г. \\
\hline Пшеница & 49,0 & 24,5 & 34,4 & 22,7 \\
\hline Рожь & 65,2 & 30,2 & 58,9 & 50,1 \\
\hline Овес & 53,3 & 19,4 & 41,4 & 22,9 \\
\hline
\end{tabular}

Источник: [33, с. 18-19].

Несмотря на плохой урожай 1916 г., необходимо констатировать, что хлеб в Саратовской губернии был. Доказательством служат многочисленные свидетельства кредитных кооперативов. Так, например, 14 товариществ Аткарского уезда определяли его в своем районе только у крестьян в 1145 тыс. пуд., 4 товарищества Петровского уезда - 126 тыс. пуд., 12 товариществ Новоузенского уезда - 2625 тыс. пуд. и т.д. [34, с. 8]. Скупщики, понимая выжидательное настроение крестьян, в свою очередь искусственно повышали цены, давая крестьянам на 2-5 коп. выше твердых.

В подобных условиях государству приходилось усиливать контроль над продовольственным делом в империи. Из-за сокращения объемов товарного хлеба 7 октября 1916 г. к практике твердых цен добавилась и разверстка. Осуществлением проекта хлебной разверстки с 29 ноября 1916 г. занялся сменивший А. А. Бобринского на посту министра земледелия А. А. Риттих. 2 декабря 1916 г. им было обнародовано положение «О разверстке зерновых хлебов и фуража, приобретаемых для потребностей, связанных с обороной» $[18$, с. 201]. Разверстано должно было быть 772,1 млн. пуд. хлеба, в том числе 285 млн. пуд. ржи, 189 млн. пуд. пшеницы, 270 млн. пуд. овса [30, с. 488]. Министерство земледелия намеревалось осуществить план разверстки в рекордно короткие сроки всего за 35 дней до 6 января 1917 г. Органы земского самоуправления должны были взять ответственность за реализацию поставок зерна [11, с. 281].

Разверстка для Саратовской губернии устанавливалась в размере 27 млн. пуд. зерна. Для обсуждения вопроса о введении в Саратовской губернии всеобщей хлебной повинности 14-15 декабря 1916 г. состоялся съезд председателей уездных земских управ под председательством К. Н. Гримма [34, с. 9-11]. В целом признавая разверстку реализуемой, съезд посчитал необходимым ходатайствовать перед Министерством земледелия об исключении из общего наряда 9 млн. пуд., объясняя это тем, что до 1 декабря 1916 г. уполномоченным уже был выполнен наряд для армии в 9 млн. пуд. всех хлебов. Саратовское земство смогло разверстать всего 460 тыс. пуд. ржи, что было значительно ниже установленной нормы. Дальнейшую же разверстку съезд постановил произвести по итогам подворной описи запасов зерна в губернии [24, с. 9]. 
Электронный научный журнал (Online). ISSN 2303-9922. http://www.vestospu.ru

В связи с этим возникает вопрос: на кого ложилась основная масса разверстанного хлеба: на крестьян или на частных владельцев? В советской историографии давался однозначный ответ: «...правительство “помещиков" не могло начать реквизицию хлеба с помещиков» [2, с. 313-314]. Однако на съезде большинство председателей уездных земских управ решили разверстать «означенное количество ржи справедливо между помещиками и крестьянами подесятинно» [25, с. 4]. В Саратовском же уезде решили поступить еще более радикально: принимая во внимание ограниченность местных хлебных запасов, признали необходимым реквизировать хлеб у частных скупщиков и мукомолов. Помимо этого саратовские земцы требовали продления срока поставки до 15 января 1917 г. (позже - до 1 февраля 1917 г.) и предоставления земству очередной партии военнопленных. С этой целью саратовский губернатор С. Д. Тверской ходатайствовал перед Министерством земледелия: «...для пользы государства помочь саратовским земледельцам убрать урожай и произвести посевы прислать еще не менее 10 тыс. военнопленных» [4, л. 40-40 об.].

Таким образом, Саратовская губерния теоретически могла поставить для армии только 18 млн. пуд. хлеба из назначенного количества, не укладываясь при этом во временные рамки, запланированные Министерством земледелия. Губернские и уездные земства России понимали невозможность реализации возложенных на них нарядов. В многочисленных ходатайствах Министерству земледелия они требовали для себя послаблений, как это видно на примере Саратовского земства. В результате целого ряда ходатайств с мест А. А. Риттиху пришлось отсрочить окончание разверстки до 1 марта 1917 г., т.е. на 54 дня [18, с. 203].

Оценивая результаты «риттиховской» разверстки для Саратовской губернии, необходимо констатировать, что уже в самом начале она продемонстрировала свою несостоятельность, а продовольственное дело в губернии закончилось катастрофой. На конец февраля 1917 г. Саратовская губерния по объему поставок ржи выполнила разверстку всего на 47\% [17, с. 178]. В чем же заключались причины неудовлетворительных итогов?

Во-первых, уполномоченные по заготовке были поставлены планом Риттиха в очень тяжелое положение. Обязанные прежде всего снабжать армию, они были вынуждены выделять значительную долю заготовленного хлеба для городского населения и поддерживать месячную норму потребления. В 1917 г. только на долю г. Саратова уполномоченным К. Н. Гриммом выделялось каждый месяц 325 тыс. пуд. муки [35, с. 15-16]. Более того, Саратовская городская дума в условиях обострившегося продовольственного вопроса на рубеже 1916-1917 гг. была вынуждена несколько раз ходатайствовать перед уполномоченным о закупке в губернии значительных партий зерна (до 2 млн. т) [19, c. 70], что также не могло не сказываться на ходе выполнения хлебозаготовок.

Во-вторых, реакцией деревни на политику разверстки стало саботирование выдвигаемых государством требований. Создавалось странное, как отмечал корреспондент земской газеты, совершенно непонятное положение: «...есть хлеб, и вместе с тем нет - нет хлеба» [26, с. 4-5]. Это практически означало отказ крестьян дать хлеб государству. Большинство из них воспринимали разверстку как невозможность и неумение государства купить хлеб. Так, по сообщению члена продовольственного губернского комитета, когда у одной крестьянки попытались реквизировать 3 мешка хлеба, она легла на них и сказала: «...лучше убейте, а хлеб не отдам, - тут все мое достояние» [23, с. 8]. Придерживать хлеб крестьян заставляло и то обстоятельство, что ожидаемый урожай 1917 г. уже в феврале земством оценивался как самый плохой за последние годы [23, с. 9].

Подводя итог вышесказанному, необходимо констатировать, что с началом Первой мировой войны в империи осуществлялись поиски наиболее эффективных и гибких ор- 
Электронный научный журнал (Online). ISSN 2303-9922. http://www.vestospu.ru

ганизационных форм снабжения армии. По этой причине становился неизбежным диалог между властью и общественными организациями. Уже в 1914 г. правительство пыталось опереться на органы земского самоуправления в решении такого сложного вопроса, как снабжение армии хлебом. Однако, расширив круг деятельности земств, государство при этом старалось умерить их возросшую самостоятельность, подчинить правительственному контролю. В условиях неконтролируемого, свободного рынка земства не могли стать самостоятельным и конкурентоспособным «игроком», так как вынуждены были находиться в русле общеимперской продовольственной политики. С объявлением разверстки в конце 1916 г. земству пришлось реализовывать крайне непопулярные среди населения принудительно-обязательные государственные меры по поставкам хлеба. Несмотря на установление прямых хозяйственных связей государства с производителем (минуя посредников) и наличие в губернии товарного хлеба, выполнить разверстку Саратовскому земству, действуя в рамках ограниченных компетенций, не удалось. Имперское правительство не смогло адекватно оценить ситуацию и создать продовольственную организацию, опирающуюся на поддержку широких общественных кругов. В итоге, когда определялась судьба воюющей страны, власть не сумела в должной мере получить, распределить и доставить по назначению продовольствие.

\section{Список использованных источников и литературы}

1. Алехина Е. В., Щербинин П. П. Продовольственные поставки для русской армии как патриотический почин деятельности Тамбовского земства // Вестник Тамбовского университета. Сер. Гуманитарные науки. 2014. № 7 (135). С. 175-180.

2. Анфимов А. М. Российская деревня в годы Первой мировой войны (1914 - февраль 1917 г.). М. : Изд-во социально-экономической литературы, 1962. 370 с.

3. Бакулова С. В. Роль органов местного самоуправления в системе государственного управления Российской империи в годы Первой мировой войны // Вестник Тверского государственного университета. Сер. История. 2016. № 1. С. 35-50.

4. Государственный архив Саратовской области (ГАСО). Ф. 2. ОП. 1. Д. 11654.

5. ГАСО. Ф. 25. ОП. 1. Д. 439.

6. ГАСО. Ф. 392. ОП. 1. Д. 1.

7. ГАСО. Ф. 392. ОП. 1. Д. 11.

8. ГАСО. Ф. 418. Оп. 1. Д. 3.

9. Ерошкин Н. П. История государственных учреждений дореволюционной России. М. : Высшая школа, 1968.368 с.

10. Жукова Л. А. Взаимодействие властных структур и органов земского самоуправления в России. 1864-1917 гг. : дис. ... д-ра ист. наук. М., 2000. 367 с.

11. Земское самоуправление в России, 1864-1918 : в 2 кн. Кн. 2 / под ред. Н. Г. Королевой. М. : Наука, 2005. 384 c.

12. Китанина Т. М. Война, хлеб и революция (Продовольственный вопрос в России. 1914 - октябрь 1917 г.). Л. : Наука, 1985. 378 с.

13. Китанина Т. М. Хлебная торговля России в конце XIX — начале XX века. Стратегия выживания, модернизационные процессы, правительственная политика. СПб. : Дмитрий Буланин, 2011. 608 с.

14. Кондратьев Н. Д. Рынок хлебов и его регулирование во время войны и революции. М. : Наука, 1991.487 с.

15. Лященко П. И. История народного хозяйства СССР : в 3 т. Т. 2. М. : Госиздат, 1952. 738 с.

16. Мацузато К. Общественная ссыпка и военно-продовольственная система России в годы Первой мировой войны // Acta Slavica Iaponica. Sapporo, 1997. Vol. 15. Р. $21-51$.

17. Мацузато К. Продразверстка А. А. Риттиха // Acta Slavica Iaponica. Sapporo, 1995. Vol. 13. P. 167— 183.

18. Оськин М. В. Продовольственная политика Министерства земледелия в период Первой мировой войны (июль 1914 - февраль 1917 г.) // Вестник Российского университета дружбы народов. Сер. История России. 2017. Т. 16, № 2. С. 190-209. DOI: 10.22363/2312-8674-2017-16-2-190-209. 
Электронный научный журнал (Online). ISSN 2303-9922. http://www.vestospu.ru

19. Пилипцов И. Н. Деятельность Саратовской городской думы по снабжению населения продовольствием в годы Первой мировой войны (по материалам журнала «Известия Саратовской городской думы») // Общество: философия, история, культура. Краснодар : Издат. дом «ХОРС», 2018. № 1. С. 68—73.

20. Погребинский А. П. Сельское хозяйство и продовольственный вопрос в России в годы Первой мировой войны // Исторические записки. Л. : Академия наук СССР, 1950. Т. 31. С. 37-60.

21. Рынков В. М. Аграрная экономика под прессом государственного администрирования: из опыта времен Первой мировой войны // Экономический журнал. 2016. № 3. С. 68-97.

22. Саратовская земская неделя. 1917. № 1, окт.

23. Саратовская земская неделя. 1917. № 7, янв.-фев.

24. Саратовский листок. 1916. № 7. 15 дек.

25. Саратовский листок. 1916. № 8.22 дек.

26. Сельскохозяйственный вестник Юго-Востока. 1916. № 20, дек.

27. Сельскохозяйственный листок Балашовского уездного земства. 1915. № 7-8, сент.

28. Сельскохозяйственный листок Балашовского уездного земства. 1915. № 9-10, окт.

29. Семенова Е. Ю. «Продовольственный вопрос» в жизни горожан Поволжья в годы Первой мировой войны // Исторические, философские, политические и юридические науки, культурология и искусствоведение. Вопросы теории и практики. 2011. № 1 (7). С. 171-178. $650 \mathrm{c}$.

30. Сидоров А. Л. Экономическое положение России в годы Первой мировой войны. М. : Наука, 1973.

31. Тагирова Н. Ф. Организация зерновой торговли в Российской империи (начало ХХ в.). Опыт сетевого анализа // Экономическая история. Ежегодник. 2013. М. : РОССПЭН, 2014. С. 74 -88.

32. Тагирова Н. Ф. Рынок Поволжья (вторая половина XIX — начало XX в.). М. : Моск. общественный фонд, 1999. 312 с.

33. Экономический бюллетень юго-востока России. 1916. № 1, окт.-нояб.

34. Экономический бюллетень юго-востока России. 1916. № 2, нояб.

35. Экономический бюллетень юго-востока России. 1916-1917. № 4, янв.-фев.

Поступила в редакцию 16.05.2019

Фортун Алексей Андреевич, аспирант

Саратовский национальный исследовательский государственный университет

им. Н. Г. Чернышевского

Российская Федерация, 410012, г. Саратов, ул. Астраханская, 83

E-mail: fortun2017@yandex.ru

UDC 94(470)“1914/1918”

\section{A. A. Fortun}

\section{Saratov Zemstvo During The World War I (1914-1917): Bread Supply to The Front}

With the outbreak of the World War I the main areas of work of Saratov Zemstvo Administration were reduced to organizing the treatment of sick and wounded soldiers, providing assistance to refugees, etc. However, as the situation on the fronts and in the rear worsened, the authorities attracted zemstvos to solve more ambitious national tasks, in particular, providing the army with bread and fodder. Using the example of Saratov province, the author notes that the state, having delegated to the zemstvos broad powers in the procurement of bread for the army, at the same time tried to localize their activities with a certain legislative control. As a result, forced to follow the general imperial food policy of the zemstvos, they could not effectively solve the assigned tasks.

Key words: World War I, Saratov province, zemstvo (county council), food supply, the commissioner for bread supplies.

Fortun Aleksei Andreevich, Postgraduate Student

Saratov State University

Russian Federation, 410012, Saratov, ul. Astrakhanskaya, 83

E-mail: fortun2017@yandex.ru 


\section{Электронный научный журнал (Online). ISSN 2303-9922. http://www.vestospu.ru}

\section{References}

1. Alekhina E. V., Shcherbinin P. P. Prodovol'stvennye postavki dlya russkoi armii kak patrioticheskii pochin deyatel'nosti Tambovskogo zemstva [Food supply for Russian army as patriotic fix activity of Tambov zemstvo]. Vestnik Tambovskogo universiteta. Ser. Gumanitarnye nauki - Tambov University Review. Series: Humanities, 2014, no. 7 (135), pp. 175-180. (In Russian)

2. Anfimov A. M. Rossiiskaya derevnya v gody Pervoi mirovoi voiny (1914 - fevral'1917 g.) [Russian village during the First World War (1914 — February 1917)]. Moscow, Izd-vo sotsial'no-ekonomicheskoi literatury Publ., 1962. 370 p. (In Russian)

3. Bakulova S. V. Rol' organov mestnogo samoupravleniya v sisteme gosudarstvennogo upravleniya Rossiiskoi imperii v gody Pervoi mirovoi voiny [The role of the local self-government in the state government system of the Russian Empire during World War I]. Vestnik Tverskogo gosudarstvennogo universiteta. Ser. Istoriya - Herald of Tver State University. Series: History, 2016, no. 1, pp. 35-50. (In Russian)

4. Gosudarstvennyi arkhiv Saratovskoi oblasti [State Archive of the Saratov Region] (GASO). F. 2. Op. 1. D. 11654 .

5. GASO. F. 25. Op. 1. D. 439.

6. GASO. F. 392. Op. 1. D. 1.

7. GASO. F. 392. Op. 1. D. 11.

8. GASO. F. 418. Op. 1. D. 3.

9. Eroshkin N. P. Istoriya gosudarstvennykh uchrezhdenii dorevolyutsionnoi Rossii [The history of state institutions of pre-revolutionary Russia]. Moscow, Vysshaya shkola Publ., 1968. 368 p. (In Russian)

10. Zhukova L. A. Vzaimodeistvie vlastnykh struktur i organov zemskogo samoupravleniya v Rossii. 18641917 gg.: dis. ... d-ra ist. nauk [The interaction of power structures and bodies of local government in Russia. 1864-1917. Dr. Dis.]. Moscow, 2000. 367 p. (In Russian)

11. Zemskoe samoupravlenie v Rossii, 1864-1918: v 2 kn. Kn. 2 [Zemstvo self-government in Russia, 1864-1918. In 2 books. Book 2]. Moscow, Nauka Publ., 2005. 384 p. (In Russian)

12. Kitanina T. M. Voina, khleb i revolyutsiya (Prodovol'stvennyi vopros v Rossii. 1914 - oktyabr' 1917 g.) [War, bread and revolution (Food issue in Russia. 1914 - October 1917)]. Leningrad, Nauka Publ., 1985. 378 p. (In Russian)

13. Kitanina T. M. Khlebnaya torgovlya Rossii v kontse XIX - nachale XX veka. Strategiya vyzhivaniya, modernizatsionnye protsessy, pravitel'stvennaya politika [Grain trade in Russia in the late XIX - early XX century. Survival strategy, modernization processes, government policy]. St. Petersburg, Dmitrii Bulanin Publ., 2011. 608 p. (In Russian)

14. Kondrat'ev N. D. Rynok khlebov i ego regulirovanie vo vremya voiny i revolyutsii [The bread market and its regulation during the war and revolution]. Moscow, Nauka Publ., 1991. 487 p. (In Russian)

15. Lyashchenko P. I. Istoriya narodnogo khozyaistva SSSR: v 3 t. T. 2 [The history of the national economy of the USSR. In 3 vol. Vol. 2]. Moscow, Gosizdat Publ., 1952. 738 p. (In Russian)

16. Matsuzato K. Obshchestvennaya ssypka i voenno-prodovol'stvennaya sistema Rossii v gody Pervoi mirovoi voiny [Public dumping and the military food system of Russia during the First World War]. Acta Slavica Iaponica. Sapporo, 1997, vol. 15, pp. 21-51. (In Russian)

17. Matsuzato K. Prodrazverstka A. A. Rittikha [Prodrozavstka (Surplus appropriation system) of A. A. Rittich]. Acta Slavica Iaponica. Sapporo, 1995, vol. 13, pp. 167-183. (In Russian)

18. Os'kin M. V. Prodovol'stvennaya politika Ministerstva zemledeliya v period Pervoi mirovoi voiny (iyul' 1914 - fevral' 1917 g.) [Food policy of the ministry of agriculture in World War I (July 1914 — February 1917)]. Vestnik Rossiiskogo universiteta druzhby narodov. Ser. Istoriya Rossii - RUDN Journal of Russian History, 2017, vol. 16, no. 2, pp. 190-209. DOI: 10.22363/2312-8674-2017-16-2-190-209. (In Russian)

19. Piliptsov I. N. Deyatel'nost' Saratovskoi gorodskoi dumy po snabzheniyu naseleniya prodovol'stviem v gody Pervoi mirovoi voiny (po materialam zhurnala "Izvestiya Saratovskoi gorodskoi dumy") [Saratov City Council activities to supply the population with food during the World War I (by a case study of Bulletin of Saratov City Council)]. Obshchestvo: filosofiya, istoriya, kul'tura - Society: Philosophy, History, Culture, 2018, no. 1, pp. 68-73. (In Russian)

20. Pogrebinskii A. P. Sel'skoe khozyaistvo i prodovol'stvennyi vopros v Rossii v gody Pervoi mirovoi voiny [Agriculture and the food issue in Russia during the First World War]. Istoricheskie zapiski [Historical notes]. Leningrad, Akademiya nauk SSSR Publ., 1950, vol. 31, pp. 37-60. (In Russian)

21. Rynkov V. M. Agrarnaya ekonomika pod pressom gosudarstvennogo administrirovaniya: iz opyta vremen Pervoi mirovoi voiny [Agrarian economy under pressure of state regulation: from the experience of World War I Time]. Ekonomicheskii zhurnal, 2016, no. 3, pp. 68-97. (In Russian)

22. Saratovskaya zemskaya nedelya, 1917, no. 1, Oct. 
Электронный научный журнал (Online). ISSN 2303-9922. http://www.vestospu.ru

23. Saratovskaya zemskaya nedelya, 1917, no. 7, Jan. - Feb.

24. Saratovskii listok, 1916, no. 7, Dec. 15.

25. Saratovskii listok, 1916, no. 8, Dec. 22.

26. Sel'skokhozyaistvennyi vestnik Yugo-Vostoka, 1916, no. 20, Dec.

27. Sel'skokhozyaistvennyi listok Balashovskogo uezdnogo zemstva, 1915, no. 7-8, Sept.

28. Sel'skokhozyaistvennyi listok Balashovskogo uezdnogo zemstva, 1915, no. 9-10, Oct.

29. Semenova E. Yu. "Prodovol'stvennyi vopros" v zhizni gorozhan Povolzh'ya v gody Pervoi mirovoi voiny ["Food issue" in the life of townspeople of the Volga region during World War I]. Istoricheskie, filosofskie, politicheskie i yuridicheskie nauki, kul'turologiya i iskusstvovedenie. Voprosy teorii i praktiki, 2011, no. 1 (7), pp. 171-178. (In Russian)

30. Sidorov A. L. Ekonomicheskoe polozhenie Rossii v gody Pervoi mirovoi voiny [The economic situation in Russia during the First World War]. Moscow, Nauka Publ., 1973. 650 p. (In Russian)

31. Tagirova N. F. Organizatsiya zernovoi torgovli v Rossiiskoi imperii (nachalo XX v.). Opyt setevogo analiza [The organization of grain trade in the Russian Empire (early XX century). Experience of network analysis]. Ekonomicheskaya istoriya. Ezhegodnik [Economic history. Yearbook]. 2013. Moscow, ROSSPEN Publ., 2014, pp. 74 -88. (In Russian)

32. Tagirova N. F. Rynok Povolzh'ya (vtoraya polovina XIX - nachalo XX v.) [Volga market (second half of XIX - early XX century)]. Moscow, Mosk. obshchestvennyi fond Publ., 1999. 312 p. (In Russian)

33. Ekonomicheskii byulleten' yugo-vostoka Rossii, 1916, no. 1, Oct. — Nov.

34. Ekonomicheskii byulleten'yugo-vostoka Rossii, 1916, no. 2, Nov.

35. Ekonomicheskii byulleten'yugo-vostoka Rossii, 1916-1917, no. 4, Jan. — Feb. 